\title{
Stability of ammonium in feldspar at high temperatures : implications for nitrogen preservation and transport in the deep Earth
}

\author{
WEIHUA HUANG ${ }^{1}$, YAN YANG ${ }^{1 *}$
}

${ }^{1}$ Key Laboratory of Geoscience Big Data and Deep

Resource of Zhejiang Province, School of Earth Sciences, Zhejiang University,Hangzhou 310027, China

(*Correspondence: : yanyang2005@zju.edu.cn)

Recent studies indicate that the mantle is the main reservoir of nitrogen. Feldspar can incorporate nitrogen as ammonium substituting for $\mathrm{K}$ in the structure, thus is one of main carriers of nitrogen to the deep Earth through plate subduction. Knowledge of behavior of ammonium in feldspar at high temperatures and high pressures is very important to understand the preservation and transfer of nitrogen during subduction. However, there is only one report of behavior of ammonium in feldspar at high pressures [1]. It suggested that ammonium in feldspar is very stable and has little interaction with the feldspar lattice under compression, which is different from behavior of ammonium in phengite at high temperatures [2,3]. To reveal ammonium behavior in feldspar at high temperatures, here, we carry out in situ FTIR spectroscopic investigations on ammonium in a hyalophane feldspar at elevated temperatures up to $1000{ }^{\circ} \mathrm{C}$, analyze evolution of the $\mathrm{N}-\mathrm{H}$ bonding strength, and fit the diffusion coefficient of nitrogen at $1000^{\circ} \mathrm{C}$.

The results show that the N-H stretching vibration band( $\left(\mathrm{v}_{3}\right)$ shifts to higher frequencies with increasing temperature to $100^{\circ} \mathrm{C}$, and then to lower frequencies at higher temperatures. This trend indicates temperature-induced hydrogen bonding weakening at temperatures lower than $100{ }^{\circ} \mathrm{C}$, and the next weakening of $\mathrm{N}-\mathrm{H}$ bonding strength, which is on the contrary to the behavior of ammonium in feldspar under compression [1]. In addition, the diffusion rate of nitrogen is about $6.5 \times 10^{-13} \mathrm{~m}^{2} / \mathrm{s}$ at $1000{ }^{\circ} \mathrm{C}$, which is one order of magnitude faster than nitrogen diffusion in phengite $\left(7.9 \times 10^{-14} \mathrm{~m}^{2} / \mathrm{s}\right.$ at $\left.1000^{\circ} \mathrm{C}\right)[3]$

This is the first report of high temperature behavior of ammonium in feldspar, and has implications for evaluating preservation and transfer of nitrogen during plate subduction.

[1] Vennari,C et al.(2017) Phys Chem Minerals 44,149-161.

[2] Yang,Y et al.(2017) American Mineralogist 102,2244-2253.

[3] Liu,W et al.(2019)Earth and Planetary Science Letters 513,95-

102. 